\title{
PARTICIPATORY EVALUATION OF IMPROVED FEED TECHNOLOGIES TO ENHANCE SMALL RUMINANT FATTENING ON PASTORALIST RESEARCH GROUP (PRG) MEMBERS IN CHIFRA DISTRICT OF AFAR NATIONAL REGIONAL STATE
}

\author{
Mohammed Nuru ${ }^{1}$ and Mohammed Yasin 2 \\ 1Socioeconomics associate researcher; Afar Pastoral and Agropastoral Research Institute, APARI, Ethiopia \\ ${ }^{2}$ Animal production lecturer; Wollo University, Ethiopia \\ Email: mnuru2000i@yahoomail.com \\ supporting Information
}

\begin{abstract}
The causes for low productivity of sheep and goat include poor veterinary services, inadequate quantity and quality of feed. Among these limiting factors, poor feed supply and feeding system is the most important. The objectives of this project were to demonstrate and evaluate Urea Molasses Multi-Nutrient Blocks (UMMNB) and concentrates mix feed technologies in participatory manner through Pastoralist Research Group (PRG) approach and look in to the perception and opinions of agro-pastoralist to the new feed and feeding techniques. The PRG has 25 members and was established a year ago. Among the PRG members, 6 trial agropastoralists were selected by the PRG members purposefully to implement the experiment. A total of $\mathbf{3 6}$ small ruminants (sheep and goat) were used for the trial. Training on UMMB preparation, formulation of concentrate feed, animal management and data collection were given for PRG members and Development Agents (DAs). The demonstration and evaluation trial were lasts for 4 months data collection period. Data were collected by the trial PRG agro-pastoralist throughout the trial period with close follow up of DAs and woreda experts. For data analysis purpose the researchers used descriptive statistics. The results showed that the final body weight and daily body weight gain was higher in grazing when supplemented with concentrates mix (Treatment 3 ) in compared to grazing + urea molasses block supplementation (T2) and control one/free grazing (T1). The partial budget analysis also indicated that small ruminant daily weight gain for 4 months with supplementation of concentrate mix supplemented groups (T3) was found to give on average economic return of 250 Ethiopian Birr (ETB) or 6.70 Euro per head. From this study, it can be concluded that the supplementation concentrate mix for small ruminants (sheep and goat) has better weight gain and economically feasible for the chifera district PRG established in 2017. It was also economical at PRG level, with average gross profit of 250 ETB per head in chifera area. Because of this, so money agro-pastoralists has been attracted by the business and engaged in small ruminant fattening practices by purchasing animals from market place without external advice and support.
\end{abstract}

Key words: Small ruminant, Urea molasses block, Feed technology, Pastoralist research group

\section{INTRODUCTION}

Sheep and goats, with their small body size, high reproductive capacity and rapid growth rates are ideally suited to production by resource-poor smallholders. They can be integrated into the overall production system, absorbing surplus labor and consuming small amounts of otherwise unused feed. Despite a large population and the contribution of the national and regional sheep and goat flock to the export earnings of the country Ethiopia in general and Afar region in particular as well as the livelihoods of households in rural and semi urban areas, their productivity is very limited. The causes for low productivity of sheep and goat are multifaceted and include poor veterinary services, inadequate quantity and quality of feed. Among these limiting factors, poor feed supply and feeding system is the most important (Alemayehu, 2002).

Extensive sheep and goat production under the traditional communal grazing/ browsing system is widely practiced in Afar region. Pasture, crop residues and browses are the main feed supply to sheep and goat in the region and such types of feeds rarely satisfy the maintenance requirements of animals. Most of the available feeds are noted for their poor feeding value in terms of protein and energy contents besides their low digestibility.) Some studies, reported that in semiarid and tropical ecosystems, the quality of forages decreases greatly during the dry season, leading to substantial weight loss of animals (Pinkerton, 2005; Njidda, 2010; Njidda and Nasiru, 2010; Amiri and Mohamed Shariff, 2012; Njidda et al, 2012). This phenomenon requires the alleviation of nutrients deficiency in animals through implementing different feed utilization strategies. Even though many studies were taken place on small ruminants in Ethiopia most of the technologies were not transferred to end users and farmers. As a result, the small ruminant development in smallholder farms remains unchanged. Hence there is a need to search for alternative technologies, which could improve the nutritive value of the poor-quality feeds to enhance the production of small ruminant. There are different techniques that could improve the 
feeding value of basal diet among which urea treatment legume supplementation and concentrates supplementation are well known for their technical and economic feasibility under smallholder Agro-pastoralist especially in developing countries. Moreover, semi-intensified market-oriented fattening of small ruminant has the potential to make smallholder Agro-pastoralist/ pastoralist more profitable.

\section{Objectives of the Study}

General objective: The general objectives of this study were to demonstrate and evaluate Urea Molasses MultiNutrient Block/UMMNB/ and concentrates mix feed technology in participatory manner through PRG approach and look in to the perception and opinions of Agro-pastoralist to the new feed and feeding techniques.

Specific objectives: A) To evaluate the response of small ruminants (goat $\&$ sheep) to the new alternative feed source-based feeding under smallholder Agro-pastoralist during drought season; B) To see the perception of Agropastoralist to the new feed and feeding techniques.

\section{METHODS AND MATERIALS}

\section{Description of the study area}

The study was undertaken in Chifra district of zone one (Awsi Rasu) of the Afar Regional State. It is located south west of Semera on the main road of Mile to Woldiya, which is about $162 \mathrm{~km}$ from the regional capital city (Semera) and bordered on the south by Mille, on the west by Amhara Region, on the north by the Administrative Zone four (Fantena Rasu), and on the East by Dubti (Zone one). The total land area of the district is about 173,374 ha of which the largest area is rangeland (APARDB, 2006). The average temperature of the area is about 29oC, and the rainfall is bimodal with erratic distribution, with the long rainy season (Kerma) is between Mid-June to Mid-September and the short rainy season (Sugum) that occurs between March and April. The average annual rainfall is recorded to be between 400 and 600 mm (APARDB, 2006). The altitude range of the area is between $>550-1,100 \mathrm{~m}$ above sea level and most of the rangelands of the study district falls below 850 m.a.s.l. The dominant soil types in these areas are black, sandy, vertosols and deposits of silt and fine sand particles occur in the plain flat areas where cultivation is practiced (APARDB, 2006). The study area consists of 19 pastoral associations of these 13 of the associations are pastoralists, which entirely depend on livestock production. The remaining 6 associations are agro-pastoralists. The district has an estimated total population of 91,078, of which 50,859 are males and 40,219 are females; 9,132 or $10.02 \%$ of its population are urban dwellers and the household numbers are 17,744 (CSA, 2007).

\section{Sampling methods of the study}

The PRG having 25 members were established in 2017. Among the PRG members, six trial agro-pastoralists were selected by the PRG members purposefully to implement the experiment. Each treatment was tested by each trial pastoralist. From all trial agro-pastoralists, 36 animals were contributed for the trial (fattening). A total of 36 small ruminants (sheep and goat) were used for the trial, thus each of the six pastoralists had six small ruminants. Training was a crucial component in introducing any new technology. Training on UMMB preparation, formulation of concentrate feed, animal management and data collection were given for PRG members and DAs. The demonstration and evaluation trial were lasts for 4 months data collection period. Data's were collected by the trial PRG Agro-pastoralist throughout the trial period with close follow up of DA's and woreda experts. Finally, data were analyzed using descriptive statistics such as (percentage, ranges, etc.).

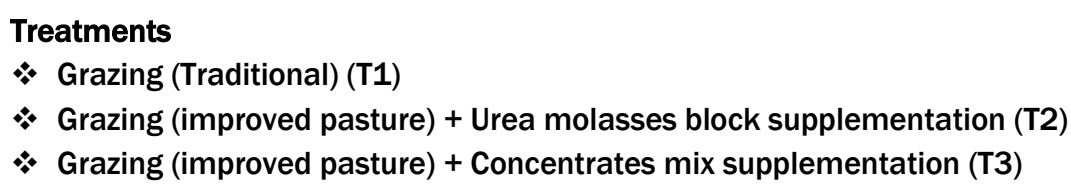

Table 1 - Ration Formulation

\begin{tabular}{|c|c|c|c|c|}
\hline \multicolumn{2}{|l|}{ Concentrate mix } & \multicolumn{2}{|c|}{ Urea Molasses Multi Nutrient Block/UMMNB/ } & Remarks \\
\hline Items & Percentage (\%) & Items & Percentage (\%) & \multirow{5}{*}{$\begin{array}{l}\text { N.B: } 2.5 \% \text { of their body } \\
\text { weight level of } \\
\text { supplement given to the } \\
\text { animal. }\end{array}$} \\
\hline Cottonseed cake & 49 & Molasses & 40 & \\
\hline Wheat bran & 50 & Urea & 10 & \\
\hline Salt & 1 & Cement & 10 & \\
\hline Total & 100 & $\begin{array}{l}\text { Salt } \\
\text { Wheat bran } \\
\text { Cotton seed cake } \\
\text { Total }\end{array}$ & $\begin{array}{l}5 \\
25 \\
10 \\
100\end{array}$ & \\
\hline
\end{tabular}




\section{RESULT AND DISCUSSION}

In this section the findings/ results of the study are presented and discussed. Accordingly, the body weight gain of the experimental sheep \& goat fed with grazing + Urea molasses block supplementation (T2) and grazing with supplemented with Concentrates mix (T3) and control one/ free grazing (T1) are presented in Table 1. The initial weight of each sheep and goat was $18.5 \mathrm{~kg}$ and $15.5 \mathrm{~kg}$ respectively. Number of animals was 12 in each of the three treatments (i.e., T1, T2, and T3). The final body weight and daily body weight gain was higher $26.5 \mathrm{~kg}$ final weight in grazing with supplemented with Concentrates mix (T3) than grazing + Urea molasses block supplementation (T2) \& control one/ free grazing (T1). In other words, the result shows, that concentrate feed supplementation (T3) results the highest body weight increment on the animals followed by UMMNB feed (T2). On the other hand, free grazing of small ruminants taken as control (T1), gives the lowest effect on animals to increase their body weight. The average daily weight gain range in sheep \& goat concentrate mix supplemented group (T3) are $0.066 \mathrm{~kg} /$ day $\& 0.066 \mathrm{~kg} /$ day respectively. The higher live weight gains of concentrate mix supplemented groups(T3) may be due to adequate amount of nutrients in concentrate mixture the CP and energy are comparable than Urea molasses block supplementation (T2) \& natural grass grazing without supplementation in (T1).

As table 2 below shows, economic return from goats is slightly higher than sheep under study. This could happen because of the community's food habits. In Afar region, goat is preferred than sheep in their diets. Likewise, goat population is higher than sheep in the region. In every households of the pastoral community of the region; goats are the dominant animals. This could be resulted from feed availability/browses, environmental, agro-climatic condition of the region, genetic make-up of the animals /goats/ adaptability to harsh climate, productivity as well as cultural practices of pastoral community in the region.

The result clearly shows that Urea molasses block supplementation (T2) and concentrate mix supplemented groups (T3) has a great influence on body weight gain of small ruminates relative to control one. Fattening of Afar sheep and goat with supplementation of cconcentrate feed for three months is highly profitable and brings better average daily weight gain as compare to animals feed on Urea molasses block supplementation (T2). The partial budget analysis indicated that small ruminant daily weight gain for 4 months with supplementation of concentrate mix supplemented groups (T3) was found to give on average economic return of $\mathbf{2 5 0}$ birr per head. For instant six agro-pastoralists in Chifra district has tried to fatten six goat \& sheep at a time while after four months they sold all goats and they got net earnings of 9000 birr. The remaining group members have been castrated their male goats for further fattening purpose. Because of this, so money agropastoralists has been attracted by the business and engaged in small ruminant fattening practices by purchasing some animals from market without external advice/support.

Table 2 - Body weight change and Economic Benefits of Afar Shoat fattening (Sheep \& Goat) by feeding UMMNB and Concentrate Supplementation in Chifra district

\begin{tabular}{|c|c|c|c|}
\hline Items & & Grazing +UMMB & Grazing+ Concentrate feed(300gm/DM) \\
\hline \multirow{2}{*}{ Initial weight(kg) } & Shee & 18.5 & 18.5 \\
\hline & Goat & 15.5 & 15.5 \\
\hline \multirow{2}{*}{ Final weight(kg) } & Shee & 25 & 26.5 \\
\hline & Goat & 22 & 23.5 \\
\hline \multirow{2}{*}{ Weight change with four months (kg) } & Shee & 6.5 & 8 \\
\hline & Goat & 6.5 & 8 \\
\hline \multirow{2}{*}{ Daily weight gain (kg) } & Shee & 0.054 & 0.066 \\
\hline & Goat & 0.054 & 0.066 \\
\hline Total cost per trial PRG & & 1600 & 1700 \\
\hline Gross return per trial PRG & & 3000 & 3200 \\
\hline Gross margin per trial PRG & & 1400 & 1500 \\
\hline Total gross output & & 18000 & 19200 \\
\hline Total costs & & 9600 & 10200 \\
\hline Total gross margin & & 8400 & 9000 \\
\hline Economic return & & 233 per animal & 250 per animal \\
\hline
\end{tabular}

\section{CONCLUSION}

This study aims to evaluate different feed technologies on small ruminants in participatory manner on pastoralist context through pastoralist research group. Three-hundred-gram concentrate mix /head/day supplementation (49\% Cottonseed cake mixed with $33 \%$ wheat bran and $1 \%$ salt) of small ruminants (sheep \& goat) has better weight gain and economically feasible for the chifera woreda established PRG. It was also economical at PRG level, with average gross profit of 250 ETB per head in chifera area. Because of this, so money agro-pastoralists has been attracted by the business and engaged in small ruminant fattening practices by purchasing some animals from market place without external advice/support. In 
the future animal fattening will be played imperative role to improve the livelihood of the poor pastoralists and agropastoralists through enhancing the daily income. Besides, agro-pastoralists and extension workers had appreciated fattening practice with concentrate mix feed supplementation than conventional fattening practice.

\section{Recommendations}

Even though promising practices had been observed during the study; there are some critical activities has to be done in order to increase benefit and support pastoral livelihoods in this endeavor. The following are recommended to be done in the future.

- Extending on-farm research and increasing numbers of PRG and numbers of agro-pastoralists in each PRG

- Continuous awareness raising to the communities on how to fatten small ruminates

- Working closely with Agro-pastoralists

- Scale up of on-farm research result

\section{DECLARATION}

Authors' contribution

Mohammed Nuru contributed in all stages of implementation including review and developing the content.

Mohammed Yasin contributed mainly on data gathering and actual implementation of the trial.

\section{Acknowledgement}

The authors would wish to acknowledge Eco Fuels Kenya LTD (EFK) for their support through the whole process of developing this publication and Mohammed Abduletife for his support and advice in this publication.

\section{Conflict of interest}

The authors declare they have no competing of interests.

\section{REFERENCES}

APADB, 2006. Baseline survey made on the Potential, Constraints, and Opportunity on the Production System of 29 woredas of Afar National Regional State, Afar Pastoral, Agricultural and Development Bureau.

Alemayehu Mengistu, 2002. Forage production in Ethiopia: A case study with implication for livestock production. Ethiopian Society of Animal Production, Ethiopia. Corpus IOD:132666144. CAB Direct I Google Scholar

Amiri F and Mohamed Shariff AR (2012) Comparison of nutritive values of grasses and legume species using forage quality index. Songklanakarin Journal of Science and Technology 34(5): 577-586. Google Scholar I URL: http://rdo.psu.ac.th/sjstweb/journal/34-5/0475-3395-34-5-577-586.pdf

CSA, (2007). Ethiopian Statistical Abstract, Central Statistical Authority, 2007, Addis Ababa, Ethiopia.

Njidda A (2010). Chemical composition, fibre fraction and anti-nutritional substances of semi-arid browse forages of northeastern Nigeria. Nigerian Journal of Basic and Applied Sciences, 18(2). DOI: http://dx.doi.org/10.4314/njbas.v18i2.64308 I Google Scholar

Njidda A, and Nasiru A. (2010). In vitro gas production and dry matter digestibility of tannin-containing forages of semi-arid region of north-eastern Nigeria. Pakistan Journal of Nutrition, 9(1), 60-66. DOI: http://dx.doi.org/10.3923/pjn.2010.60.66 I Google Scholar

Njidda A, Olatunji E, and Raji A (2012). Semi-arid browse forages: Their antinutritive substances and in Sacco neutral detergent fibre and organic matter degradability., 1(6), 21-30. Google Scholar

Pinkerton B (2005). Forage quality. Clemson University Cooperative Extension Service. Forage fact sheet 2. Google Scholar 